\title{
Family Involvement with MD \& A (Management Disclosure \& Analysis) Readability Level
}

\author{
Diarany Sucahyati, Iman Harymawan and Tubagus Algan Roiston \\ Faculty of Economy and Business, Universitas Airlangga, Surabaya \\ Email: harymawan.iman@feb.unair.ac.id
}

\begin{abstract}
This study aims to examine the relationship between family involvement and the readability level of the MD \& A (Management Disclosure \& Analysis) released by the company. This study uses 1795 final samples from firms listed on the Indonesia Stock Exchange in the period 2010-2018. We tested the research hypothesis using ordinary least square regression (OLS). This was done using the Stata software by adding a fixed effect for industry diversity in order to strengthen the study results. This study used two proxies of the family firm where there is the involvement of family members at the management level and related to the ownership of company shares. Both of these proxies show consistent results indicating that family firms tend to release less readable MD\&As. Furthermore, the language differences were also tested in this study. Apart from the presentation of the MD\&A in English or Indonesian, family firms still present reports with lower readability. This study provides a perspective to the authorities regarding the family firm's governance intended to help improve existing regulations.
\end{abstract}

Keywords: Family Firm, Readability, MD \& A, Management Disclosure \& Analysis.

\begin{abstract}
Abstrak: Penelitian ini bertujuan meneliti hubungan keterlibatan keluarga dengan tingkat keterbacaan MD \& A (Management Disclosure \& Analysis) yang dirilis perusahaan. Penelitian ini menggunakan 1795 sampel final dari perusahaan yang listing di Bursa Efek Indonesia periode 2010-2018. Untuk menguji hipotesis penelitian digunakan regresi ordinary least square (OLS) yang dilakukan melalui software Stata dengan menambahkan fixed effect keragaman industri dan tahun untuk memperkuat hasil penelitian. Penelitian ini menggunakan dua proxy perusahaan keluarga yaitu keterlibatan anggota keluarga di manajemen dan kepemilkan saham perusahaan, keduanya menunjukkan hasil yang konsisten bahwa perusahaan keluarga memiliki kecenderungan untuk merilis MD\&A yang lebih rendah keterbacaannya. Lebih lanjut, perbedaan bahasa juga diuji didalam penelitian ini dan terlepas dari penyajian MD\&A didalam bahasa inggris atau pun bahasa Indonesia, perusahaan keluarga tetap menyajikan laporan tersebut dengan keterbacaan yang lebih rendah. Penelitian ini diharapkan memberi pandangan bagi regulator mengenai tata kelola perusahaan khususnya perusahaan keluarga, sehingga otoritas terkait bisa semakin meningkatkan peraturan yang ada.
\end{abstract}

Kata Kunci: Perusahaan Keluarga, Keterbacaan, MD \& A, Management Disclosure \& Analysis. 


\section{INTRODUCTION}

In emerging markets such as Indonesia, company reporting is a specific source of company information that reflects the quality of the capital market (Hesarzadeh and Rajabalizadeh, 2019). An annual report is a form of company reporting that contains the directors' and board of commissioners' responsibilities in reference to managing and supervising the issuers or public firms within 1 (one) financial year (OJK, 2016). The annual report must at least contain an overview of the important financial data, stock information, the directors' report, the board of commissioners' report, the profiles of the issuers or public firms, the management analysis and discussion, the issuer's governance, the issuers' social and environmental responsibility, audited annual financial reports, and a statement from the members of the board of directors and the board of commissioners regarding their responsibility related to the annual report (OJK, 2016). Textual narratives represent most of the disclosure of this information or about $80 \%$ of the content of annual reports, while the rest is represented by quantitative data (Lo et al., 2017). Therefore, the clarity of the nonnumerical part (textual narrative) is essential to fully convey the company information to the stakeholders. In general, lower clarity can weaken the accuracy and absorption of the information (Lawrence, 2013).

Research by (Li, 2008) and (Ong et al., 2020) found that a more readable annual report is correlated with better financial performance. The readability of the company's annual report also reflects the transparency of the financial information to some extent, thus providing a valuation basis for the shareholders who participate in corporate investment decisions and prevent investment inefficiencies (Zhao et al., 2020). (Boubaker et al., 2019) found that stock liquidity is related to the company's annual report readability. Annual reports that are difficult to read hinder the investors' ability to process and analyze the information in the company's annual report. This reduces their willingness to trade, which also reduces the stock liquidity. The readability of the financial statement footnote in the annual report can provide audit engagement risk information. Firms with less readable footnotes have longer audit report lag, incur higher audit costs, and they are more likely to accept a modified going-concern opinion for the first time (Albernathy et al., 2019). Furthermore, in the same study, the readability of the footnotes is associated with the possibility of higher financial misstatements and litigation related to accounting in the future.

High readability is an essential element in the quality of company reporting. However, this behavior may differ in certain types of firm. Previous research found that family firms have different reporting strategies than non-family firms (Cascino et al., 2010; Ding, Qu, \& Zhuang, 2011). As a source of information for stakeholders, the annual report might voice concerns for the managers, so they need to obscure some information to change the stakeholder perceptions (Merkl-Davies and Brennan, 2007). The family management may want to hide one or two things from the other stakeholders (non-family members). This is undoubtedly related to the issue of family reputation and the desire to promote a positive image. Opportunistic family management might increase the perception of the company achievements or it can conceal information that could negatively affect their position (Hooghiemstra, 2000), although this means that information asymmetry has occurred. This has the potential to cause agency conflict (Cheng, 2014).

Readability research related to firms has not been a topic widely discussed by 
researchers. The research by (Drago et al., 2017) became the first to discuss this topic and it shows different results to this study. The family firm in this study had a low level of readability. Family firms may still have the same reputation goals but they have a different attitude. In the research of (Drago et al., 2017), family firms promote their positive image by increasing transparency through report readability. However, in developing capital markets, negative issues can be sensitive for investors. Therefore, family firms prefer to hide information that is perceived as negative rather than disclose the truth.

This research used the data of firms listed on the Indonesia Stock Exchange in 20102018. Family firms were measured using two proxies: the involvement of the family members in the management and the level of family share ownership of the company. Furthermore, the clarity of the textual narratives or readability can be measured through the readability scores. There are five scoring methods for textual narrative readability referring to the readability software version 1.0 used. The methods are the Flesch-Kincaid Grade Level (FKG), the Flesch-Kincaid Readability Index (FKR), the Gunning-Fog Readability Index (FOG), the Simple Measure of Gobbledygook (SMOG), and the Coleman-Liau Readability Index (CLR). This study measures the readability of the company's MD\&A contained in the annual report. This is because $80 \%$ of the information in the financial statements is summarized in the form of qualitative information in the Management Discussion and Analysis (MD\&A) section (Li, 2012). The research hypothesis was tested using ordinary least square regression (OLS) conducted using Stata software by adding a fixed effect for industry diversity to strengthen the research results.

\section{THEORETICAL REVIEW}

Research by (Claessens et al., 2000) in East Asian countries found that more than $50 \%$ of firms in Indonesia are controlled by families. The family business has become one of the phenomena that cannot be separated from developing countries besides political connections (Muttakin et al., 2015). Centralized share ownership, the strong monitoring of the owners, and management involvement across the generations within a family are the hallmarks of this type of company (Xu et al., 2015). Family firms have high productivity compared to non-family firms due to the family-oriented work environment and the longterm view of the family members that the company assets are assets that can be passed on to future generations (Matherne et al., 2017). This certainly encourages the family firms to focus on protecting the company's image and reputation (Berrone et al., 2012). This is because reputation also affects the family name in addition to the company name (Zellweger et al., 2011).

Family involvement in the family business is very visible in companies (Craig et al., 2008). As the visibility of the family in the company is getting higher, so it leads to more blurred in the boundary between the family and the company. In consequences, the family identity in business cannot be separated from the company (Deephouse and Jaskiewicz, 2013). Corporate image is an important component of corporate identity (Glynn and Abzug, 2002). The firm carries the family name, so there are consequences that corporate behavior will have a strong impact on the image and reputation of the family (Binz et al., 2013; DeMassis et al., 2016). Family identities bind group members to shared goals and pride in fulfilling family company obligations (Berrone et al., 2012; Zellweger et al., 2013). 
Managers feel a sense of urgency to obscure some of the information in the annual report to change the stakeholder's perception (Merkl-Davies and Brennan, 2007). Although the annual report is a specific source of information for the stakeholders, the issue of family reputation and the desire to promote a positive image becomes more of a priority. Opportunistic family management might increase the perception of the company achievements or conceal information that could negatively affect their position (Hooghiemstra, 2000).

H1: The readability level of MD\&A in a family firm is lower than the readability level in a non-family firm.

\section{METHODOLOGY}

Sample and Data Source. The initial sample of this study amounted to 5404 firms from the Indonesia Stock Exchange in the period 2010-2018. The sample excludes industrial sector (SIC) number 6, namely banking and financial institutions. This is because they have different characteristics to the firms in other industrial sectors, such as cash and cash equivalents. (Sánchez and Yurdagul, 2013) suggested that by excluding firms in industrial sector number 6 , the research conducted would be more comparable.

Furthermore, the MD \& As of the firms that were not available in a foreign language (English) were excluded from the sample. This requirement is also applicable to the MD \& As of the firms that could not be copied and any missing or damaged annual reports. The annual report, based on the rules from the Financial Services Authority of the Republic of Indonesia NUMBER 29 /POJK.04/2016 article 5, must be presented in two languages, namely Indonesian and a foreign language (English). In reality, there are still many annual reports that are only presented in Indonesian. This study specifies the publication of the MD\&A in a foreign language so then the results of this study can be generalized to the previous research.

Table 1. Sample Selection

\begin{tabular}{lc}
\hline \multicolumn{1}{c}{ Specification } & Total \\
\hline Total of firms that listed on IDX in 2010-2018 & 5404 Firms \\
\hline Excluded: & \\
\hline Firms with SIC number 6 & 927 Firms \\
\hline Firms with uncomplete MD\&A & 2555 Firms \\
\hline Firms with uncomplete financial data & $127 \quad$ Firms \\
\hline Total Firms as research sample & 1795 Firms \\
\hline
\end{tabular}

Source: (Data processed, 2020)

Generally, the research data was divided into two groups, specifically financial and non-financial data. The financial data, such as the total assets and total debt, was obtained from the Orbis database. The non-financial data, such as the MD\&A readability and the family businesses themselves, was collected manually. The MD\&A readability data was collected manually by copying the MD\&A section in the annual report into the readability software version 1.0 to get the readability score. The family firm data was collected from 
the ICMD (Indonesia Capital Market Directory) report by marking the same last name or clan in the management positions and in the data on company share ownership.

\section{Variables Definition}

Dependent Variable (Readability \& MD\&A). The annual report, once published, is one of the primary sources of information for the company's stakeholders. Around $80 \%$ of the information in the financial statements is summarized in the form of qualitative information in the Management Discussion and Analysis (MD\&A) section (Lo et al., 2017). Management disclosure through the MD\&A reflects the management's attitude and it has even become a way of rationalizing the management's behavior $(\mathrm{Li}, 2012)$. However, the manager's confusion often causes this qualitative information to be difficult to understand (Hasan, 2018).

There are five readability measurement proxies (READ) in the version 1.0 readability software used by the author. These proxies are the Flesch-Kincaid Grade Level (FKG), the Flesch-Kincaid Readability Index (FKR), the Gunning-Fog Readability Index (FOG), the Simple Measure of Gobbledygook (SMOG), and the Coleman-Liau Readability Index (CL). Descriptions related to each proxy's calculation model will be explained further below, in addition to the decryption used in the measurement software.

Flesch-Kincaid Grade Level $(\boldsymbol{F K G})$. This readability test is used extensively in the field of education. FKG translates scores from 0-100 to the level of the US class, making it easier for teachers, parents, librarians, and others to assess the readability level of various books and texts. This can also be interpreted as the number of education years generally needed to understand the text, which is relevant when the formula produces a number greater than 12 . The grade level is calculated using the following formula:

$$
F K G=0.39+\left(\frac{\text { total words }}{\text { total sentences }}\right)+11.8\left(\frac{\text { total syllables }}{\text { total words }}\right)-15.59
$$

The result is a number that matches the grade level. For example, a score of 8.2 will indicate that the text is expected to be understood by the average student in grade 8 (usually around the age of 13-14 in the United States).

\section{Flesch-Kincaid Readability Index (FKR)}

In the Flesch-Kincaid Readability Index (FKR), higher scores indicate that the material is easier to read whereas lower scores indicate that the material is more difficult to read. Long words affect this score significantly more than grade level scores. The formula for calculating FKR scores is as follows:

$$
F K R=206.835-1.015+\left(\frac{\text { total words }}{\text { total sentences }}\right)-84.6\left(\frac{\text { total syllables }}{\text { total words }}\right)
$$

The scores can be interpreted as follows:

90.0-100.0 - Easy to understand for the average 11-year-old student. 60.0-70.0 - Easy to understand for the average 11-15-year-old student. $0.0-30.0$ - Mostly understood by the average university graduate. 
Gunning-Fog Readability Index (FOG). The Gunning-Fog Readability Index (FOG) depends on the average number of words per sentence and the percentage of complex words in a document to measure the document's readability. The higher the score, the worse the readability of the document. The following formula is used to calculate the FOG score:

$$
F O G=0.4 \times\left(\left(\frac{\text { words }}{\text { sentence }}\right)-100\left(\frac{\text { complex words }}{\text { words }}\right)\right)
$$

Simple Measure of Gobbledygook (SMOG). This readability formula estimates the years of education needed to understand the writing fully. SMOG is widely used, especially for checking health messages. The SMOG formula produces a correlation of 0.985 with a standard error of 1.5159 values with a reader score that has a $100 \%$ understanding of the test material. McLaughlin published SMOG in 1969 as a more accurate and easier substitute for the Gunning-Fog index. The following formula can calculate the level of readability:

$S M O G=$ grade $-1.043 \sqrt{30 \times \frac{\text { number of polysyllables }}{\text { number of sentences }}}-3.1291$

Coleman-Liau Readability Index $(\boldsymbol{C L R})$. This readability test was designed by Coleman and Liau to measure the ability to understand a text. Like the Flesch-Kincaid Level, the Gunning-Fog Index, the SMOG Index, and the Automated Readability Index, the output approaches the level of the US class that is considered necessary to understand the text. The Coleman-Liau Readability Index (CLR) relies on characters rather than syllables per word. Although there are variations in opinion regarding its accuracy compared to complex syllables/words and word indices, characters are more easily and accurately calculated by computer programs than syllables. To calculate the CLR, the following formula was used:

$C L I=5.89 \times\left(\frac{\text { characters }}{\text { words }}\right)-29.5\left(\frac{\text { sentences }}{\text { words }}\right)-15.8$

Independent Variable (Family Firm). The firm is defined as a family firm (FF) if there are one or more family members who hold positions as members of the board of directors, as the CEO or by having family shareholding that makes up at least $5 \%$ of the (Chen, Chen, \& Cheng, 2008; Zhou, He, \& Wang, 2017). This study used a proxy for the family members' involvement at the managerial level to see how family management plays a role in producing MD\&A reports. The involvement of family members indirectly represents a substantial family presence in the ownership, governance, management, and succession of the firm (O'Boyle, Rutherford, \& Pollack, 2010). Through the reference of SEOJK No. 30SEOJK.04-2016, it is explained that public companies in Indonesia must disclose if there is any affiliation between the directors and commissioners in their annual reports. This study also re-examined every affiliated relationship found in the annual report to confirm the relationship.

Control Variable. In this study, two groups of control variables were used. First there is the group of corporate financial performance variables which includes $R \boldsymbol{O A}, \boldsymbol{F I R M S I Z E}$,

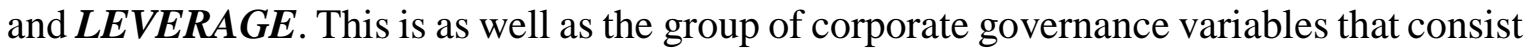
of the number of directors (DIR), the number of commissioners (COM), the percentage of 
independent directors (INDDIR), and the percentage of independent directors (INDCOM).

\section{THE RESULTS OF STATISTICAL TESTS}

To reduce the occurrence of human error, the data processing in this study was carried out using the Stata software. Figure 1 shows the percentage of the number of family members involved in managing the company in the position of either commissioners or directors. Additionally, $61 \%$ of family firms involve two family members, followed by $25 \%$ involving three people, $9 \%$ involving four people, $4 \%$ involving five people, and $1 \%$ involving six people.

Figure 1. Family Members Involved in Management of the Company

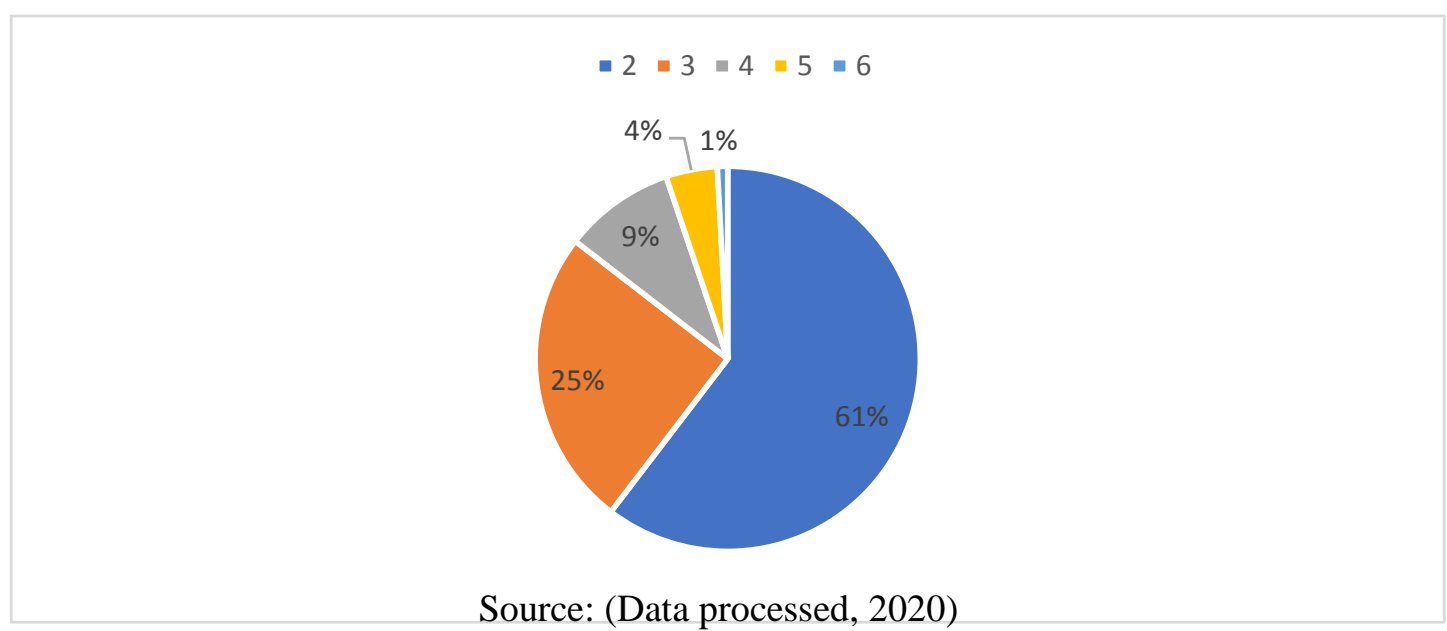

Table 2 shows the distribution of the samples per year regarding the family and nonfamily firms. In general, there is an increase in the sample of family firms every year, although a decline occurred in 2014 and 2016.

Table 2. Sample Distribution per Year $(n=1795)$

\begin{tabular}{cccc}
\hline TAHUN & $\sum$ Family Firms & $\sum$ Non Family Firms & $\begin{array}{c}\sum \text { Total } \\
\text { Firms }\end{array}$ \\
\hline $\mathbf{2 0 1 0}$ & 43 & 97 & 140 \\
$\mathbf{2 0 1 1}$ & 47 & 115 & 162 \\
$\mathbf{2 0 1 2}$ & 54 & 127 & 181 \\
$\mathbf{2 0 1 3}$ & 55 & 105 & 160 \\
$\mathbf{2 0 1 4}$ & 48 & 122 & 170 \\
$\mathbf{2 0 1 5}$ & 75 & 137 & 212 \\
$\mathbf{2 0 1 6}$ & 65 & 134 & 199 \\
$\mathbf{2 0 1 7}$ & 86 & 178 & 264 \\
$\mathbf{2 0 1 8}$ & 101 & 206 & 307 \\
\hline TOTAL & 574 & 1221 & 1795 \\
\hline
\end{tabular}

Source: (Data processed, 2020) 
Table 3 shows the distribution of the research samples based on nine industry classifications made by the USA government. This classification is based on the company's main business units. In this study, sector number 6, namely banking and financial institutions, was excluded. The largest distribution of family firms is in the construction industry sector at $44 \%$, followed by the agriculture, forestry, and fishing sector and the wholesale and retail trade sectors respectively at 39\%. Last is the manufacturing sector at $33 \%$.

Table 3. Sample Distribution Based on Industry $(n=1795)$

\begin{tabular}{|c|c|c|c|c|c|c|c|}
\hline \multirow{2}{*}{ SIC } & \multirow{2}{*}{ INDUSTRY } & \multicolumn{2}{|c|}{$F F$} & \multicolumn{2}{|c|}{ NON-FF } & \multicolumn{2}{|c|}{ TOTAL } \\
\hline & & $\mathbf{N}$ & $\%$ & $\mathbf{N}$ & $\%$ & $\mathbf{N}$ & $\%$ \\
\hline 0 & Agriculture, Forestry, and Fishing & 27 & $39 \%$ & 42 & $61 \%$ & 69 & $100 \%$ \\
\hline 1 & Mining & 58 & $19 \%$ & 244 & $81 \%$ & 302 & $100 \%$ \\
\hline 2 & Construction Industries & 211 & $44 \%$ & 270 & $56 \%$ & 481 & $100 \%$ \\
\hline 3 & Manufacturing & 103 & $33 \%$ & 206 & $67 \%$ & 309 & $100 \%$ \\
\hline 4 & Transportation, Communication and Utilities & 78 & $26 \%$ & 217 & $74 \%$ & 295 & $100 \%$ \\
\hline 5 & Wholesale and Retail Trade & 63 & $39 \%$ & 97 & $61 \%$ & 160 & $100 \%$ \\
\hline 7 & Services Industries & 26 & $18 \%$ & 120 & $82 \%$ & 146 & $100 \%$ \\
\hline 8 & $\begin{array}{l}\text { Health, Legal and Educational Services and } \\
\text { Consulting }\end{array}$ & 8 & $24 \%$ & 25 & $76 \%$ & 33 & $100 \%$ \\
\hline $\mathbf{T O}^{\prime}$ & $\mathbf{A L}$ & 574 & & 1221 & & 1795 & \\
\hline
\end{tabular}

Source: (Data processed, 2020)

Table 4 shows the descriptive statistics that include the average value, the middle value, the lowest value, and the highest value of the variables used in this study. In this table, the variable values are presented after the Winsorized treatment, in addition to the original values before $\ln$ or $\log$. This study used the five types of readability score of FKG, FKR, GF, SMOG, and CL to measure the MD\&As readability. The family firms were measured using a dummy variable.

Table 4. Descriptive Statistics $(n=1795)$

\begin{tabular}{lcccc}
\hline & MEAN & MEDIAN & MINIMUM & MAXIMUM \\
\hline FKG & 14.633 & 14.636 & 6.549 & 27.131 \\
FKR & -28.893 & -29.205 & -74.625 & 39.378 \\
FOG & 18.913 & 19.017 & 8.273 & 31.499 \\
SMOG & 16.658 & 16.678 & 10.025 & 38.974 \\
$\boldsymbol{C L R}$ & 17.070 & 17.013 & 1.838 & 28.621 \\
FF & 0.320 & 0.000 & 0.000 & 1.000 \\
ROA & 5.533 & 4.580 & -36.910 & 49.770 \\
FIRMSIZE $($ TASSET) & $7,656,000,000$ & $2,486,000,000$ & $38,620,000$ & $86,790,000,000$ \\
LEVERAGE & 0.526 & 0.500 & 0.048 & 2.492 \\
DIR & 4.833 & 5.000 & 2.000 & 15.000 \\
INDDIR & 0.576 & 1.000 & 0.000 & 4.000 \\
COM & 4.267 & 4.000 & 1.000 & 13.000 \\
INDCOM & 1.579 & 1.000 & 0.000 & 6.000 \\
\hline SOIF: $($ Da & & & &
\end{tabular}

Source: (Data processed, 2020) 
Table 5 indicates the Firm Characteristics. It presents the comparison of the characteristics between two groups of firms. In this study, we have presented a comparison of the readability score characteristics between family and non-family firms. Panel A compares the Flesch-Kincaid Grade Level $(\boldsymbol{F} \boldsymbol{K G})$ readability score characteristics between family and non-family firms. The coefficient of $\boldsymbol{F} \boldsymbol{K} \boldsymbol{G}$ is $-5,453$ and it is significant at the 1\% level. Panel B compares the readability score characteristics of the Flesch-Kincaid Readability Index (FKR) between family and non-family firms. The coefficient of $\boldsymbol{F} \boldsymbol{K} \boldsymbol{R}$ is $-5,641$ and it is significant at the $1 \%$ level. Panel $C$ compares the readability score characteristics of the Gunning-Fog Readability Index (FOG) between family and nonfamily firms. The coefficient of $\boldsymbol{F O G}$ is $-6,833$ and it is significant at the $1 \%$ level. Panel D compares the Simple Measure of Gobbledygook (SMOG) readability score characteristics between family and non-family firms. The coefficient of $\boldsymbol{S M O G}$ is -6.050 and it is significant at the $1 \%$ level. Panel E compares the Coleman-Liau Readability Index $(\boldsymbol{C L R})$ readability scores between family and non-family firms. The coefficient of $\boldsymbol{C L}$ is $-3,670$, and the significance level is $1 \%$. These results explain that family firms in Indonesia have lower readability scores than non-family firms.

Tabel 5. Firm Characteristic $(n=1795)$

Panel A MD\&A Readability level (FKG) of Family Firms $(F F)$

\begin{tabular}{lcccc}
\hline & $\boldsymbol{F F}$ & Non- $\boldsymbol{F} \boldsymbol{F}$ & MEAN & MEDIAN \\
\cline { 2 - 5 } & $\mathbf{n}=\mathbf{5 7 4}$ & $\mathbf{n = 1 2 2 1}$ & t-value & z-value \\
\hline $\boldsymbol{F K G}$ & 14.246 & 14.815 & $-5.453^{* * *}$ & $-4.939^{* * * *}$ \\
\hline
\end{tabular}

Panel B MD\&A Readability level (FKR ) of Family Firms $(F F)$

\begin{tabular}{lcccc}
\hline & $\boldsymbol{F F}$ & Non- $\boldsymbol{F} \boldsymbol{F}$ & MEAN & MEDIAN \\
\cline { 2 - 5 } & $\mathbf{n}=\mathbf{5 7 4}$ & $\mathbf{n = 1 2 2 1}$ & t-value & z-value \\
\hline $\boldsymbol{F K R}$ & -30.835 & -27.980 & $-5.641^{* * *}$ & $-6.671^{* * * *}$ \\
\hline
\end{tabular}

Panel C MD\&A Readability level $(G F)$ of Family Firms $(F F)$

\begin{tabular}{lcccc}
\hline & $\boldsymbol{F F}$ & Non-FF & MEAN & MEDIAN \\
\cline { 2 - 5 } & $\mathbf{n = 5 7 4}$ & $\mathbf{n = 1 2 2 1}$ & t-value & z-value \\
\hline $\boldsymbol{G F}$ & 18.369 & 19.168 & $-6.833^{* * *}$ & $-6.346^{* * *}$ \\
\hline
\end{tabular}

Panel D MD\&A Readability level (SMOG) of Family Firms (FF)

\begin{tabular}{lcccc}
\hline & $\boldsymbol{F F}$ & Non-FF & MEAN & MEDIAN \\
\cline { 2 - 5 } & $\mathbf{n}=\mathbf{5 7 4}$ & $\mathbf{n = 1 2 2 1}$ & t-value & z-value \\
\hline SMOG & 16.292 & 16.830 & $-6.050^{* * * *}$ & $-5.665^{* * * *}$ \\
\hline
\end{tabular}

Panel E MD\&A Readability level (CLR) of Family Firms (FF)

\begin{tabular}{lcccc}
\hline & $\boldsymbol{F F}$ & Non-FF & MEAN & MEDIAN \\
\cline { 2 - 5 } & $\mathbf{n}=\mathbf{5 7 4}$ & $\mathbf{n = 1 2 2 1}$ & t-value & z-value \\
\hline $\boldsymbol{C L R}$ & 16.873 & 17.163 & $-3.670^{* * *}$ & $-4.562^{* * *}$ \\
\hline
\end{tabular}

Source: (Data processed, 2020)

Stata, significant in $10 \%, 5 \%$ and $1 \%$. 
Table 6 refers to the Pearson correlation which shows the random correlation matrix between the variables used in this study. This matrix measures the dependence and direction of the linear relationship between two variables (Zhou et al., 2017). The direction of the relationship is marked by a positive or negative sign while the significance level indicates the strength of the relationship. The results show that family firms $(\boldsymbol{F F})$ have a significant negative relationship with the five readability proxies $(\boldsymbol{F K G}, \boldsymbol{F K R}, \boldsymbol{G F}, \boldsymbol{S M O G}, \boldsymbol{C L})$.

The first hypothesis (H1) of this study estimates that the MD\&A readability level in family firms is lower than the readability in non-family firms. To test this hypothesis, we used multiple linear regression (OLS) and equation (1). This model includes a set of performance control and corporate governance variables. This study also controls for the fixed effect on industry diversity and years to strengthen the results. The details of the equation are presented as follows:

$$
\begin{array}{r}
R E A D: \alpha+\beta 1 F F+\beta 2 R O A+\beta 3 F I R M S I Z E+\beta 4 L E V E R A G E+\beta 5 D I R+ \\
\beta 6 I N D D I R+\beta 7 C O M+\beta 8 I N D C O M+\beta 9 Y E A R+\beta 10 I N D U S T R Y+\varepsilon . .
\end{array}
$$

\begin{tabular}{|c|c|c|c|c|c|c|c|c|c|c|c|}
\hline & [1] & [2] & [3] & [4] & [5] & {$[6]$} & [7] & {$[8]$} & [9] & [10] & [11] \\
\hline$[1] F K G$ & 1.000 & & & & & & & & & & \\
\hline \multirow[t]{2}{*}{ [2] FKR } & $0.867^{* * *}$ & 1.000 & & & & & & & & & \\
\hline & $(0.000)$ & & & & & & & & & & \\
\hline \multirow[t]{2}{*}{ [3] $G F$} & $0.860^{* * * *}$ & $0.826^{* * *}$ & 1.000 & & & & & & & & \\
\hline & $(0.000)$ & $(0.000)$ & & & & & & & & & \\
\hline \multirow{2}{*}{$\begin{array}{l}{[4]} \\
\text { SMOG }\end{array}$} & $0.901^{* * *}$ & $0.763^{* * *}$ & $0.793^{* * *}$ & 1.000 & & & & & & & \\
\hline & $(0.000)$ & $(0.000)$ & $(0.000)$ & & & & & & & & \\
\hline \multirow[t]{2}{*}{ [5]CLR } & $0.554^{* * *}$ & $0.739^{* * *}$ & $0.529^{* * *}$ & $0.469^{* * *}$ & 1.000 & & & & & & \\
\hline & $(0.000)$ & $(0.000)$ & $(0.000)$ & $(0.000)$ & & & & & & & \\
\hline \multirow[t]{2}{*}[6]{$F F$} & $-0.128^{* * *}$ & $-0.132^{* * *}$ & $-0.159^{* * * *}$ & - & - & 1.000 & & & & & \\
\hline & $(0.000)$ & $(0.000)$ & $(0.000)$ & $\begin{array}{l}0.141 \\
(0.000)\end{array}$ & $\begin{array}{l}0.086 \\
(0.000)\end{array}$ & & & & & & \\
\hline \multirow{2}{*}{ [7] $\mathrm{ROA}$} & 0.037 & $0.041^{*}$ & 0.035 & 0.020 & $0.044^{*}$ & 0.035 & 1.000 & & & & \\
\hline & $(0.122)$ & $(0.084)$ & $(0.133)$ & $(0.408)$ & $(0.062)$ & $(0.140)$ & & & & & \\
\hline \multirow{2}{*}{$\begin{array}{l}{[8]} \\
\text { FIRMSI } \\
\text { ZE }\end{array}$} & $0.206^{* * *}$ & $0.159^{* * *}$ & $0.165^{* * *}$ & $0.197^{* * *}$ & $0.166^{* * *}$ & -0.016 & $0.117^{* * *}$ & 1.000 & & & \\
\hline & $(0.000)$ & $(0.000)$ & $(0.000)$ & $(0.000)$ & $(0.000)$ & $(0.490)$ & $(0.000)$ & & & & \\
\hline \multirow{3}{*}{$\begin{array}{l}{[9]} \\
\text { LEVERA } \\
\text { GE }\end{array}$} & -0.019 & -0.015 & -0.031 & -0.037 & - & - & - & -0.004 & 1.000 & & \\
\hline & & & & & & & & & & & \\
\hline & $(0.414)$ & $(0.534)$ & $(0.187)$ & $(0.118)$ & $(0.022)$ & $(0.000)$ & $(0.000)$ & $(0.873$ & & & \\
\hline \multirow[t]{2}{*}[10]{$\mathrm{DIR}$} & $0.128^{* * *}$ & $0.098^{* * *}$ & $0.083^{* * *}$ & $0.112^{* * *}$ & $0.087^{* * *}$ & $0.103^{* * *}$ & $0.208^{* * *}$ & $0.479^{*}$ & $\overline{-}^{-} .058^{* *}$ & 1.000 & \\
\hline & $(0.000)$ & $(0.000)$ & $(0.000)$ & $(0.000)$ & $(0.000)$ & $(0.000)$ & $(0.000)$ & $\begin{array}{c}(0.000 \\
)\end{array}$ & $(0.015)$ & & \\
\hline \multirow[t]{2}{*}{$\begin{array}{l}{[11]} \\
\text { INDDIR }\end{array}$} & $0.063^{* * *}$ & $0.060^{* *}$ & $0.075^{* * *}$ & $0.079^{* * *}$ & $0.070^{* * *}$ & $\stackrel{-}{-}^{-055^{* *}}$ & $\overline{-}^{-}$ & $0.092^{*}$ & $\begin{array}{c}- \\
0.086^{* *} \\
{ }^{*}\end{array}$ & $\underset{*}{-263^{* *}}$ & $\begin{array}{c}1.00 \\
0\end{array}$ \\
\hline & $(0.007)$ & $(0.011)$ & $(0.002)$ & $(0.001)$ & $(0.003)$ & $(0.020)$ & $(0.000)$ & $\begin{array}{c}(0.000 \\
)\end{array}$ & $(0.000)$ & $(0.000)$ & \\
\hline [12] & $0.175^{* * *}$ & $0.136^{* * *}$ & $0.151^{* * *}$ & $0.157^{* * *}$ & $0.108^{* * *}$ & -0.020 & $0.160^{* * *}$ & $0.512^{*}$ & -0.031 & $0.490^{* *}$ & - \\
\hline
\end{tabular}

Table 6. Pearson Correlation $(n=1795)$ 


\begin{tabular}{|c|c|c|c|c|c|c|c|c|c|c|c|}
\hline \multirow[t]{2}{*}{ COM } & & & & & & & & $* *$ & & * & 0.15 \\
\hline & $(0.000)$ & $(0.000)$ & $(0.000)$ & $(0.000)$ & $(0.000)$ & $(0.404)$ & $(0.000)$ & (0.000 & $(0.183)$ & $(0.000)$ & $\begin{array}{c}2 \\
(0.00 \\
0)\end{array}$ \\
\hline \multirow{2}{*}{$\begin{array}{l}{[13]} \\
\text { INDCO } \\
M\end{array}$} & 0.032 & 0.031 & $0.052^{* *}$ & 0.036 & 0.029 & 0.013 & $0.052^{* *}$ & $0.066^{*}$ & 0.028 & -0.005 & 0.12 \\
\hline & $(0.176)$ & $(0.185)$ & $(0.028)$ & $(0.131)$ & $(0.226)$ & $(0.572)$ & $(0.027)$ & $\begin{array}{c}(0.005 \\
)\end{array}$ & $(0.233)$ & $(0.833)$ & $\begin{array}{c}(0.00 \\
0)\end{array}$ \\
\hline
\end{tabular}

Source: (Data processed, 2020)

Stata, significant in $10 \%, 5 \%$ and $1 \%$.

Table 7 presents the OLS regression results for the first hypothesis. The first specification uses the readability proxy of the Flesch-Kincaid Grade Level $(\boldsymbol{F} \boldsymbol{K} \boldsymbol{G})$, which has a coefficient of -0.499 and is significant at $1 \%(\mathrm{t}=-4.83)$. The second specification shows the readability proxy of the Flesch-Kincaid Readability Index $(\boldsymbol{F K R})$, which has a coefficient of -2.593 and is significant at $1 \%(\mathrm{t}=-5.19)$. The third specification uses the readability proxy of the Gunning-Fog Readability Index $(\boldsymbol{F O G})$, which has a coefficient of -0.715 and is significant at $1 \%(\mathrm{t}=-6.05)$. The fourth specification uses the readability proxy of the Simple Measure of Gobbledygook (SMOG), which has a coefficient of -0.473 and is significant at $1 \%(\mathrm{t}=-5.46)$. The fifth specification uses the readability proxy of the Coleman-Liau Readability Index $(\boldsymbol{C L R})$, which has a coefficient of -0.286 and is significant at $1 \%(\mathrm{t}=-3.74)$. The results of testing the specifications of $1-5$ imply that the level of MD\&A readability in family firms (managerial family) is lower than that of non-family firms for all readability measurement proxies.

Table 7. Regression of Family Firms $(F F)$ with the MD\&A Report Readability

\begin{tabular}{|c|c|c|c|c|c|}
\hline & \multicolumn{5}{|c|}{$R E A D$} \\
\hline & $F K G$ & FKR & $F O G$ & SMOG & CLR \\
\hline & (1) & (2) & (3) & (4) & (5) \\
\hline \multirow[t]{2}{*}{$F F$} & $-0.499^{* * *}$ & $-2.593^{* * *}$ & $-0.715^{* * *}$ & $-0.473^{* * *}$ & $-0.286^{* * *}$ \\
\hline & $(-4.83)$ & $(-5.19)$ & $(-6.05)$ & $(-5.46)$ & $(-3.74)$ \\
\hline \multirow{2}{*}{$R O A$} & 0.004 & 0.031 & 0.004 & 0.001 & 0.005 \\
\hline & (1.04) & $(1.53)$ & $(1.00)$ & $(0.30)$ & $(1.50)$ \\
\hline \multirow[t]{2}{*}{ FIRMSIZE } & $0.154^{* * * *}$ & $0.530^{* * * *}$ & $0.125^{* * *}$ & $0.129^{* * * *}$ & $0.112^{* * *}$ \\
\hline & $(3.62)$ & $(2.67)$ & $(2.60)$ & $(3.73)$ & $(3.46)$ \\
\hline \multirow{2}{*}{ LEVERAGE } & -0.097 & -0.232 & -0.213 & -0.197 & -0.202 \\
\hline & $(-0.61)$ & $(-0.24)$ & $(-1.20)$ & $(-1.57)$ & $(-1.42)$ \\
\hline \multirow[t]{2}{*}{ DIR } & $0.071^{* *}$ & $0.310^{* *}$ & 0.048 & $0.057^{* * *}$ & 0.029 \\
\hline & $(2.32)$ & (1.99) & (1.42) & $(2.05)$ & (1.20) \\
\hline \multirow[t]{2}{*}{ INDDIR } & $0.915^{* *}$ & 2.025 & $1.051^{* *}$ & $0.794^{* *}$ & 0.131 \\
\hline & $(2.22)$ & (1.00) & $(2.28)$ & $(2.36)$ & $(0.44)$ \\
\hline \multirow[t]{2}{*}{ COM } & $0.097^{* * * *}$ & $0.343^{* *}$ & $0.119^{* * *}$ & $0.071^{* *}$ & 0.027 \\
\hline & (2.99) & $(2.32)$ & $(3.29)$ & $(2.42)$ & (1.14) \\
\hline \multirow[t]{2}{*}{ INDCOM } & 0.200 & 1.157 & 0.551 & 0.192 & 0.099 \\
\hline & $(0.65)$ & $(0.71)$ & $(1.45)$ & $(0.74)$ & $(0.40)$ \\
\hline \multirow[t]{2}{*}{ CONSTANT } & $8.627^{* * * *}$ & $-52.346^{* * *}$ & $13.448^{* * *}$ & $11.630^{* * *}$ & $13.154^{* * * *}$ \\
\hline & $(7.34)$ & $(-9.63)$ & (9.90) & $(12.10)$ & $(14.28)$ \\
\hline
\end{tabular}




\begin{tabular}{lccccc}
$\begin{array}{l}\text { Year Dummies } \\
\text { Industry Dummies }\end{array}$ & $\begin{array}{c}\text { Included } \\
\text { Included }\end{array}$ & $\begin{array}{c}\text { Included } \\
\text { Included }\end{array}$ & $\begin{array}{c}\text { Included } \\
\text { Included }\end{array}$ & $\begin{array}{c}\text { Included } \\
\text { Included }\end{array}$ & $\begin{array}{c}\text { Included } \\
\text { Included }\end{array}$ \\
\hline R-Squared & 0.122 & 0.119 & 0.103 & 0.118 & 0.102 \\
Number of Observation & 1795 & 1795 & 1795 & 1795 & 1795 \\
\hline
\end{tabular}

Source: Stata, significant in $10 \%, 5 \%$ and $1 \%$.

Table 8 presents the OLS regression results used to strengthen the first hypothesis test in this study. Table 7 uses a family firm proxy related to the involvement of family members at the management level while Table 8 uses the family firm proxy of family shareholding, if it is at least 5\%. Specification 1 uses the Flesch-Kincaid Grade Level (FKG) readability proxy, which has a coefficient of -0.285 and is significant at the $5 \%$ level $(\mathrm{t}=-2.28)$. Specification 2 uses the Flesch-Kincaid Readability Index $(\boldsymbol{F} \boldsymbol{K R})$ readability proxy, which has a coefficient of -2.111 and is significant at $1 \%(\mathrm{t}=-3.86)$. Specification 3 uses the readability proxy of the Gunning-Fog Readability Index $(\boldsymbol{F O} \boldsymbol{O})$, which has a coefficient of -0.344 and is significant at $5 \%(t=-2.39)$. Specification 4 uses the Simple Measure of Gobbledygook (SMOG) readability proxy, which has a coefficient of -0.189 and is significant at $10 \%(\mathrm{t}=-1.83)$. Specification 5 uses the Coleman-Liau Readability Index $(\boldsymbol{C L R})$ readability proxy, which has a coefficient of -0.290 and is significant at $1 \%(\mathrm{t}=-$ 3.20). The testing specifications of 1-5 imply that the readability of the MD\&A in a family firm (family share ownership) is lower than that of a non-family firm. This result also reinforces that family firms, in terms of management and family share ownership, have a low MD\&A report readability score according to all five readability proxies.

Table 8. Regression of Family Firms $(F F 2)$ with the MD\&A Report Readability

\begin{tabular}{|c|c|c|c|c|c|}
\hline & \multicolumn{5}{|c|}{$R E A D$} \\
\hline & $F K G$ & FKR & FOG & SMOG & CLR \\
\hline & (1) & (2) & (3) & (4) & (5) \\
\hline \multirow[t]{2}{*}{ FF2(Ownership) } & $-0.285^{* *}$ & $-2.111^{* * *}$ & $-0.344^{* *}$ & $-0.189^{*}$ & $-0.290^{* * *}$ \\
\hline & $(-2.28)$ & $(-3.86)$ & $(-2.39)$ & $(-1.83)$ & $(-3.20)$ \\
\hline \multirow[t]{2}{*}{ ROA } & 0.004 & 0.028 & 0.004 & 0.001 & 0.005 \\
\hline & $(0.96)$ & (1.39) & $(0.93)$ & $(0.27)$ & (1.39) \\
\hline \multirow[t]{2}{*}{ FIRMSIZE } & $0.141^{* * * *}$ & $0.422^{* *}$ & $0.110^{* * *}$ & $0.122^{* * *}$ & $0.096^{* * *}$ \\
\hline & $(3.26)$ & $(2.08)$ & $(2.26)$ & $(3.48)$ & $(2.93)$ \\
\hline \multirow[t]{2}{*}{ LEVERAGE } & -0.031 & 0.079 & -0.115 & -0.131 & -0.170 \\
\hline & $(-0.19)$ & $(0.08)$ & $(-0.65)$ & $(-1.04)$ & $(-1.23)$ \\
\hline \multirow[t]{2}{*}{ DIR } & $0.055^{*}$ & 0.221 & 0.025 & 0.042 & 0.019 \\
\hline & $(1.80)$ & (1.44) & $(0.74)$ & (1.53) & $(0.78)$ \\
\hline \multirow[t]{2}{*}{ INDDIR } & $1.021^{* *}$ & 2.593 & $1.200^{* * *}$ & $0.892^{* * *}$ & 0.195 \\
\hline & $(2.47)$ & $(1.28)$ & $(2.59)$ & $(2.62)$ & $(0.65)$ \\
\hline \multirow[t]{2}{*}{ COM } & $0.110^{* * * *}$ & $0.424^{* * * *}$ & $0.137^{* * * *}$ & $0.082^{* * *}$ & 0.037 \\
\hline & $(3.41)$ & $(2.89)$ & $(3.78)$ & $(2.82)$ & (1.57) \\
\hline \multirow[t]{2}{*}{ INDCOM } & 0.176 & 1.057 & 0.514 & 0.165 & 0.091 \\
\hline & $(0.57)$ & $(0.65)$ & (1.37) & $(0.65)$ & $(0.37)$ \\
\hline \multirow[t]{2}{*}{ CONSTANT } & $8.863^{* * *}$ & $-49.880^{* * * *}$ & $13.660^{* * * *}$ & $11.696^{* * *}$ & $13.539^{* * *}$ \\
\hline & $(7.41)$ & $(-8.93)$ & $(9.88)$ & $(12.03)$ & $(14.36)$ \\
\hline
\end{tabular}




\begin{tabular}{lccccc}
$\begin{array}{l}\text { Year Dummies } \\
\text { Industry } \\
\text { Dummies }\end{array}$ & $\begin{array}{l}\text { Included } \\
\text { Included }\end{array}$ & $\begin{array}{c}\text { Included } \\
\text { Included }\end{array}$ & $\begin{array}{c}\text { Included } \\
\text { Included }\end{array}$ & $\begin{array}{l}\text { Included } \\
\text { Included }\end{array}$ & $\begin{array}{c}\text { Included } \\
\text { Included }\end{array}$ \\
\hline $\begin{array}{l}\text { R-Squared } \\
\text { Number of }\end{array}$ & 0.114 & 0.112 & 0.087 & 0.105 & 0.101 \\
Observation & 1795 & 1795 & 1795 & 1795 & 1795 \\
\hline
\end{tabular}

Source: (Data processed, 2020)

Stata, significant in $10 \%, 5 \%$ and $1 \%$.

Table 9 presents the OLS regression results used to strengthen the first hypothesis test. In the research related to readability, language differences often become an issue of generalizing the results. Reducing the language bias is required by testing the MD\&A report in the Indonesian language. Indonesian is a mandatory language that applies to Indonesia. The number of MD\&A samples in the Indonesian language is more than those in the foreign language (English) because not all companies present annual reports in 2 languages, even though the relevant authority (OJK) has asked this as a requirement. Specification 1 uses the Flesch-Kincaid Grade Level $(\boldsymbol{F K G})$ readability proxy. This has a coefficient of -0.430 and it is significant at the $1 \%$ level $(\mathrm{t}=-5.36)$. Specification 2 uses the Flesch-Kincaid Readability Index $(\boldsymbol{F K R})$ readability proxy, which has a coefficient of -1.677 and a significance level of $1 \%(\mathrm{t}=-4.32)$. Specifications 3 uses the readability proxy of the Gunning-Fog Readability Index (FOG), which shows a coefficient of -0.533 and it is significant at the $1 \%$ level $(\mathrm{t}=-6.04)$. Specification 4 uses the Simple Measure of Gobbledygook (SMOG) readability proxy, which has a coefficient of $-0,404$ and it is significant at $1 \%(\mathrm{t}=-5.04)$. Specification 5 uses the Coleman-Liau Readability Index $(\boldsymbol{C L R})$ readability proxy, which has a coefficient of -0.281 and it is significant at $1 \%(\mathrm{t}=-$ 4.89). The results of the testing specifications of 1-5 reinforce the results that the level of readability of the MD\&A in family firms is lower than that of non-family firms. These results remain consistent with the different languages of report submission that were used.

Table 9. Regression of Family Firms $(F F)$ with the Readability of Indonesian Language MD\&A Report

\begin{tabular}{lccccc}
\hline & \multicolumn{5}{c}{$\boldsymbol{R E A D}$} \\
\cline { 2 - 6 } & $\boldsymbol{F K G}$ & $\boldsymbol{F K R}$ & $\boldsymbol{F O G}$ & $\boldsymbol{S M O G}$ & $\boldsymbol{C L R}$ \\
\cline { 2 - 6 } $\boldsymbol{F F}$ & $(\mathbf{1})$ & $(\mathbf{2})$ & $\mathbf{( 3 )}$ & $\mathbf{( 4 )}$ & $(\mathbf{5})$ \\
\multirow{2}{*}{$\boldsymbol{R O A}$} & $-0.427^{* * * *}$ & $-1.667^{* * *}$ & $-0.530^{* * *}$ & $-0.401^{* * *}$ & $-0.281^{* * *}$ \\
& $(-5.36)$ & $(-4.32)$ & $(-6.04)$ & $(-5.04)$ & $(-4.89)$ \\
$\boldsymbol{F I R M S I Z E}$ & $0.008^{* * *}$ & $0.046^{* * * *}$ & $0.012^{* * *}$ & $0.008^{* * *}$ & $0.008^{* * *}$ \\
& $(2.74)$ & $(3.59)$ & $(3.50)$ & $(2.69)$ & $(3.42)$ \\
LEVERAGE & $0.076^{* *}$ & 0.034 & 0.034 & $0.113^{* * *}$ & -0.035 \\
& $(2.52)$ & $(0.25)$ & $(0.99)$ & $(3.65)$ & $(-1.58)$ \\
DIR & $-0.248^{*}$ & $-1.165^{*}$ & $-0.349^{* *}$ & $-0.243^{* *}$ & $-0.171^{*}$ \\
& $(-1.95)$ & $(-1.91)$ & $(-2.58)$ & $(-2.00)$ & $(-1.82)$ \\
$\boldsymbol{I N D D I R}$ & $0.071^{* * *}$ & 0.190 & $0.075^{* * *}$ & $0.084^{* * *}$ & -0.004 \\
& $(2.74)$ & $(1.63)$ & $(2.64)$ & $(3.35)$ & $(-0.23)$ \\
& $1.074^{* * *}$ & 1.695 & $1.251^{* * *}$ & $1.321^{* * *}$ & -0.272
\end{tabular}




\begin{tabular}{lccccc} 
& $(3.34)$ & $(1.06)$ & $(3.53)$ & $(4.15)$ & $(-1.25)$ \\
COM & $0.050^{*}$ & 0.075 & $0.056^{* *}$ & $0.059^{* *}$ & -0.017 \\
& $(1.93)$ & $(0.71)$ & $(2.01)$ & $(2.19)$ & $(-1.07)$ \\
& $0.382^{*}$ & 0.309 & $0.429^{*}$ & 0.207 & 0.264 \\
CONSTANT & $(1.66)$ & $(0.29)$ & $(1.66)$ & $(0.92)$ & $(1.50)$ \\
& $18.347^{* * *}$ & $20.162^{* * *}$ & $23.228^{* * *}$ & $15.474^{* * *}$ & $24.268^{* * *}$ \\
& $(21.73)$ & $(5.34)$ & $(24.74)$ & $(17.99)$ & $(38.62)$ \\
\hline Year Dummies & Included & Included & Included & Included & Included \\
Industry Dummies & Included & Included & Included & Included & Included \\
\hline R-Squared & 0.090 & 0.057 & 0.092 & 0.105 & 0.052 \\
Number of Observation & 2269 & 2269 & 2269 & 2269 & 2269 \\
\hline
\end{tabular}

Source: (Data processed, 2020)

Stata, significant in $10 \%, 5 \%$ and $1 \%$.

\section{DISCUSSION}

This study used two proxies for the family firms, namely the involvement of the family members in the company management and share ownership. To measure the readability, five textual narrative readability scoring methods were used including the Flesch-Kincaid Grade Level (FKG), the Flesch-Kincaid Readability Index (FKR), the Gunning-Fog Readability Index (FOG), the Simple Measure of Gobbledygook (SMOG) and the ColemanLiau Readability Index (CLR). Both proxies in the five scoring methods consistently show that family firms tend to release less readable MD\&A reports.

High readability is an important element in the quality of corporate reporting. However, family firms have a different pattern. The behavioral agency theory elucidates how family firms tend to evade losing their personal wealth (Nordqvist et al., 2015). One of them is social-emotional wealth (SEW) related to reputation (Berrone et al., 2010). For family firms, reputation is not merely related to the company but also the honor of the family and their personal names (Zellweger et al., 2011). This underlies the management of the family prefers to hide one or two things from the other stakeholders (non-family members) who are thought to cause a negative image (Hooghiemstra, 2000). Capital markets in developing countries that are more vulnerable to the shock issue foster an opportunistic nature of management that is done by increasing the perception of the positive company achievements and hiding information that can negatively affect their position. Family management has emotional and reputation incentives to exert influence and oversee company decisions (De Massis et al., 2014). Strengthened with control over company shares, the family has the option to not responding to the requests of minority stakeholders (Biswas et al., 2019).

The study also found that public companies in Indonesia have not fully complied with government reporting regulations. This can be seen from the availability of MD\&A in Indonesian, which is more than MD\&A in foreign languages (English), although the relevant authorities require the presentation of reports in these two languages.

Furthermore, language differences were also tested in this study found negative results, in which family firms presenting MD\&A in both English and Indonesian with lower readability. The anguage issue is one of the most debated in readability research. This index may be made specifically for the context of a particular language, so testing it in two 
different languages, namely the original language of readability and the original language of the annual report, will reduce this bias.

\section{CONCLUSION}

This study found the negative relationship between family involvement and the readability level of the MD\&A (Management Disclosure \& Analysis) released by the company. This study used two proxies of the family firm where there is the involvement of family members at the management level and related to the ownership of company shares. Both of these proxies show consistent results indicating that family firms tend to release less readable MD\&As. Apart from the presentation of the MD\&A in English or Indonesian, family firms still present reports with lower readability. Readability research related to firms has not been a topic widely discussed by researchers. Future research can further deepen family involvement through the involvement of the founder and family generation in the firm.

\section{REFERENCES}

Abernathy, J. L., Guo, F., Kubick, T. R., and Masli, A. (2019). Financial Statement Footnote Readability and Corporate Audit Outcomes. AUDITING: A Journal of Practice \& Theory, 38(2), 1-26. doi:10.2308/ajpt-52243.

Binz, C., Hair, J. F., Pieper, T. M., and Baldauf, A. (2013). Exploring the effect of distinct family firm reputation on consumers' preferences. Journal of Family Business Strategy, 4(1), 3-11. doi:10.1016/j.jfbs.2012.12.004.

Biswas, P. K., Roberts, H., and Whiting, R. H. (2019). The impact of family vs non-family governance contingencies on CSR reporting in Bangladesh. Management Decision, 57(10), 2758-2781. doi:10.1108/md-11-2017-1072.

Berrone, P., Cruz, C., Gomez-Mejia, L. R., and Larraza-Kintana, M. (2010). Socioemotional Wealth and Corporate Responses to Institutional Pressures: Do Family-Controlled Firms Pollute Less? Administrative Science Quarterly, 55(1), 82-113. doi:10.2189/asqu.2010.55.1.82.

Berrone, P., Cruz, C., and Gomez-Mejia, L. R. (2012). Socioemotional Wealth in Family Firms. Family Business Review, 25(3), 258-279. doi:10.1177/0894486511435355.

Boubaker, S., Gounopoulos, D., and Rjiba, H. (2019). Annual report readability and stock liquidity. Financial Markets, Institutions \& Instruments, 28(2), 159-186. doi:10.1111/fmii.12110.

Brennan, N., Guillamon-Saorin, E., and Pierce, A. (2009). Impression management: Developing and illustrating a scheme of analysis for narrative disclosures - A methodological note. Accounting, Auditing and Accountability Journal, 22(5), 789832. https://doi.org/10.2139/ssrn.1284904.

Cascino, S., Pugliese, A., Mussolino, D., and Sansone, C. (2010). The Influence of Family Ownership on the Quality of Accounting Information. Family Business Review, 23(3), 246-265. doi:10.1177/0894486510374302.

Chen, S., Chen, X. and Cheng, Q. (2008). Do Family Firms Provide More or Less Voluntary Disclosure? Journal of Accounting Research, 46(3), 499-536. doi:10.1111/j.1475679x.2008.00288.x. 
Cheng, Q. (2014). Family firm research - A review. China Journal of Accounting Research, 7(3), 149-163. https://doi.org/10.1016/j.cjar.2014.03.002.

Claessens, S., and Djankov, S. (2000). East Asian corporations. World Bank Discussion Papers. doi:10.1596/0-8213-4631-8.

Craig, J. B., Dibrell, C., and Davis, P. S. (2008). Leveraging Family-Based Brand Identity to Enhance Firm Competitiveness and Performance in Family Businesses. Journal of Small Business Management, 46(3), 351-371. doi:10.1111/j.1540627x.2008.00248.x.

De Massis, A., Kotlar, J., Mazzola, P., Minola, T., and Sciascia, S. (2016). Conflicting selves: Family owners' multiple goals and self-control agency problems in private firms. Entrepreneurship Theory \& Practice. http://dx.doi.org/10.1111/etap.12257.

Ding, S., Qu, B., and Zhuang, Z. (2011). Accounting Properties of Chinese Family Firms. Journal of Accounting, Auditing \& Finance, 26(4), 623-640. doi:10.1177/0148558x11409147.

Deephouse, D. L., and Jaskiewicz, P. (2013). Do Family Firms Have Better Reputations Than Non-Family Firms? An Integration of Socioemotional Wealth and Social Identity Theories. Journal of Management Studies, 50(3), 337-360. doi:10.1111/joms.12015.

Drago, C., Ginesti, G., Pongelli, C., and Sciascia, S. (2018). Reporting strategies: What makes family firms beat around the bush? Family-related antecedents of annual report readability. Journal of Family Business Strategy, 9(2), 142-150. doi:10.1016/j.jfbs.2017.11.006.

Glynn, M. A., and Abzug, R. (2002). Institutionalizing Identity: Symbolic Isomorphism and Organizational Names. Academy of Management Journal, 45(1), 267-280. doi:10.5465/3069296.

Hasan, M. M. (2018). Readability of narrative disclosures in 10-K reports: Does managerial ability matter? European Accounting Review. https://doi.org/10.1080/09638180.2018.1528169.

Hesarzadeh, R., and Rajabalizadeh, J. (2019). The impact of corporate reporting readability on informational efficiency. Asian Review of Accounting, 27(4), 489-507. doi:10.1108/ara-11-2018-0203.

Hooghiemstra, R. (2000). Corporate Communication and Impression Management - New Perspectives Why Companies Engage in Corporate Social Reporting. Business Challenging Business Ethics: New Instruments for Coping with Diversity in International Business, 55-68. doi:10.1007/978-94-011-4311-0_7.

Lawrence, A. (2013). Individual investors and financial disclosure. Journal of Accounting and Economics, 56(1), 130-147. doi:10.1016/j.jacceco.2013.05.001

Li, F. (2008). Annual report readability, current earnings, and earnings persistence. Journal of Accounting and Economics, 45(2-3), 221-247. doi:10.1016/j.jacceco.2008.02.003.

Li, F. (2012). Discussion of Analyzing Speech to Detect Financial Misreporting. Journal of Accounting Research, 50(2), 393-400. doi:10.1111/j.1475-679x.2012.00451.x.

Lo, K., Ramos, F., and Rogo, R. (2017). Earnings management and annual report readability. Journal of Accounting and Economics, 63(1), 1-25. doi:10.1016/j.jacceco.2016.09.002.

Matherne, C., Waterwall, B., Ring, J. K., and Credo, K. (2017). Beyond organizational identification: The legitimization and robustness of family identification in the family 
firm. Journal of Family Business Strategy, 8(3), 170-184. https://doi.org/10.1016/j.jfbs.2017.08.001.

Muttakin, M. B., Monem, R. M., Khan, A., and Subramaniam, N. (2015). Family firms, firm performance and political connections: Evidence from Bangladesh. Journal of Contemporary Accounting \& Economics. https://doi.org/10.1016/j.jcae.2015.09.001.

Nordqvist, M., Kumeto, G., Melin, L., and Waldkirch, M. (2015). Theoretical Perspectives on Family Businesses. doi:10.4337/9781783479665.

O'Boyle, E. H., Rutherford, M. W., and Pollack, J. M. (2010). Examining the Relation Between Ethical Focus and Financial Performance in Family Firms: An Exploratory Study. Family Business Review, 23(4), 310-326. doi:10.1177/0894486510375412.

Ong, T. S., Teh, B. H., Seng, K. C., and Ng, S. H. (2020). Does Information Overload of Annual Reports Matter? International Journal of Financial Research, 11(2), 243. doi:10.5430/ijfr.v11n2p243.

Peraturan Otoritas Jasa Keuangan Nomor 29 /Pojk.04/2016 Tentang Laporan Tahunan Emiten Atau Perusahaan Publik.

Sánchez, J. M., and Yurdagul, E. (2013). Why Are U.S. Firms Holding So Much Cash? An Exploration of Cross-Sectional Variation. Review, 95(4). doi:10.20955/r.95.293-325.

Zellweger, T., Sieger, P., and Halter, F. (2011). Should I stay or should I go? Career choice intentions of students with family business background. Journal of Business Venturing, 26(5), 521-536. doi:10.1016/j.jbusvent.2010.04.001.

Zellweger, T. M., Nason, R. S., Nordqvist, M., and Brush, C. G. (2013). Why Do Family Firms Strive for Nonfinancial Goals? An Organizational Identity Perspective. Entrepreneurship Theory and Practice, 37(2), 229-248. doi:10.1111/j.15406520.2011.00466.x.

Zhou, H., He, F., and Wang, Y. (2017). Did family firms perform better during the financial crisis? New insights from the S\&P 500 firms. Global Finance Journal, 33, 88-103. https://doi.org/10.1016/j.gfj.2017.01.001.

Zhao, Y., Liu, F., Liu, C., Usman, M., Dutta, K.D. (2020). Readability of annual report and inefficient investment: Evidence from debt financing | [Metinès ataskaitos aiškumas ir neefektyvus investavimas: Skolų finansavimo įrodymai].Transformations in Business and Economics. 19(1), pp. 166-190.

Xu, N., Yuan, Q., Jiang, X., and Chan, K. C. (2015). Founder's Political Connections, Second Generation Involvement, And Family Firm Performance: Evidence from China. Journal of Corporate Finance. https://doi.org/10.1016/j.jcorpfin.2015.01.004. 